\title{
Looking In (/): A Case Study of Northeast with Special Reference to Tripura Buranji (1724)
}

\author{
Bhaskar Jyoti Gogoi \\ Ph.D Research Scholar, English E Foreign Language University, Shillong Campus, \\ Meghalaya.bhaskargogoi@hotmail.co.in
}

\begin{abstract}
In the context of Assam, travel writing is an area which offers immense possibilities. Particularly, the precolonial period of Assam contains various neglected travelogues like the anonymous Loss of Ter Schelling (1682), Bartholomew Plaisted's Journals (1767), James Renell's Bengal Atlas (1779) and his Journals (1764-67) as well as John Peter Wade's An Account of Assam (180o). These travelogues not only are precious testimonials to the political, social and economic demographics of the period but also offer valuable insight into early Anglo-Assamese relations. Even travel narratives written in the vernacular provide critical insights about various ethnic communities residing in Northeast India. The improvement of communication networks in the seventeenth century, like trade routes and river passageways, facilitated the greater movement of travellers to and from the Northeast in various garbs like that of the explorers, invaders, missionaries etc. A pioneer amongst travel texts in Assamese is Tripura Buranji (1724), written jointly by Ratna Kandali Sarma and Arjundas Bairagi, the two Assamese envoys of King Rudra Simha (16961714) who were sent to the court of Ratnamanikya, the King of Tripura in 1714 to seek assistance for the proposed invasion of Bengal. Owing to this event, there were various correspondences and envoys being sent to and fro from the Ahom court to the King of Tripura. The two envoys mentioned here undertook the journey to Tripura on foot accompanied by escorts through Cachar and the foothills of Lushai Hills (present day Mizoram) to the capital of Ratnamanikya. The most striking fact about the travelogue is that its authors supplemented their account of the diplomatic missions, either on their own accord or on the instructions of their Government, by their observations on the resources, topography, customs and history of the country which they visited and of the territories which they had passed. Such a compilation was expected to extend the bounds of knowledge of their countrymen and facilitate the prosecution of similar missions in future. It also marks the importance of the realization of such archiving and documentation of travel as early as the eighteenth century. This paper offers introspection into this medieval narrative and presents a comparative viewpoint with Bartholomew Plaisted's Journals (1767), written around the same time period. This would offer us a comparative viewpoint vis-à-vis the insider and the outsider's narration of/about the Northeast.
\end{abstract}

Keywords: Assamese travel, eighteenth century, Tripura, diplomatic mission

Travel writing as a genre has always been subjected to a variety of criticisms down the centuries. Ranging from Jonathan Swift (1726) calling such books as 'ignorant' to being labelled as 'secondrated' by Paul Fussell (1980), the genre of travel writing has been subjected to a variety of mixed responses down the centuries. However, the genre has proven quite resilient to even the harshest of criticisms and has undoubtedly become one of the most popular and widely read forms of literature. These negative publicity, as well as sensational mongering, has somewhat shaped the contours of the genre and become an integral part of it.

\footnotetext{
(c) AesthetixMS 2020. This Open Access article is published under a Creative Commons Attribution Non-Commercial 4.o International License (http://creativecommons.org/licenses/by-nc/4.o/), which permits non-commercial re-use, distribution, and reproduction in any medium, provided the original work is properly cited. For citation use the DOI. For commercial re-use, please contact editor@rupkatha.com.
} 
Travel writing has been most aptly but somewhat a bit naively seen as retailers of mostly white, male, middle-class, heterosexual myths and prejudices, and their readers as eager consumers of exotic-culturally 'othered' goods. However, with the advent of postcolonial as well as postcolonial critics of travel and travel writing, the genre has come out of its reputation as mild reading to garner its spot and interest amongst the academics of the era. Along with it, it is now no more seen only as a byproduct of ethnocentricism but revolves around much more complex issues like its defamiliarizing capacities. Moreover, by its attempt, it tries to keep pace with change and adjusts its sights to new perceptions - both of 'other' cultures and places and also of the writer's and the reader's own cultures. Travel writing thus belongs to a wider structure of representation within which cultural affiliations and cultural understanding are analyzed, questioned, and reassessed.

As exemplified by various thinkers like Edward Said, Clifford Geertz, and David Kaplan, the ubiquitousness of 'traveling theory' is a sign no doubt that the world as it opens up to the physical movement, requires its citizens to conceptually take note of migration of people, movement of goods and travel of ideas. Yet this also indicates a utopian impulse of 'worldly' intellectual elite. It even emphasizes highly intellectualized metaphors of movement at the expense of more prosaic but powerful myths of place. Thus, travel writing as a genre and the theories of travel writing oscillates frivolously between the theorization of travel-as-displacement and that of its naively untheorised celebration of travel-as-freedom. It also encapsulates theories of it as a more or less elaborate textual performance (Butor, 2009) and as an economically sanctioned activity, a circumscribed material practice (Pratt, 2002). Emphasized amongst these are also the privileges that accrue to the (Western) traveller-writer: privileges in part to crude economic advantages and also in part to more sophisticated techniques of rhetorical control.

As a literary/cultural form, travel writing emerges as a practiced art of dissimulation; conscious of itself and at the same time being generally elusive and empirically disingenuous, it is deliberately dissembling and unclear. Travel narratives, like their writers, tend to conceal as much as they reveal: their factual disclosures are screens for cannily structured fictions, and their confessions are masks for motivational doubts and fears. One source of anxiety here is the alertness to complicity; for travel writers often participate as tourists they claim to scorn. Another is the awareness of belatedness; whereby travel writers hearken back to their precursors, seeking solace for a troubled present in nostalgic cultural spirits. These anxieties of traveller-writers are again often linked to a sense of threatening cultural origins coupled with the pleasures of curiosity for new experiences of place. These compelling pulls are fully exemplified in the travel narratives of the 'English gentleman', particularly in the 19th century; whereby they deliberately seek to reinstall a mythicized imperial past. During these eras, these myths of places get articulated in the narratives of these traveller-writers to articulate their own and also to re-express other, staged (mis)encounters. The tropes like 'the Orient', 'the tropics', 'the South Seas', and 'the Arctic' are the topoi that lend themselves to prevalent modes of imperialist nostalgia and atavistic stereotypes about original cultural representation. In the process, new mythologies have evolved, adjusting themselves to modern realities -- emigration, media imperialism, AIDS, transculturation -- addressing themselves to an audience well attuned to (trans)national politics and to the complex global circuitry of the information age.

Thus, one thing that comes out to the forefront in the evaluation of travel writing is the promiscuous contradictions that are inherent in one of the most hybrid and unassimilable of literary genres. The foremost amongst many contradictions lay the fact that travel writing is largely unpolemical, yet the statement itself is its strongest critique. Though it is most often than 
not seen as a literary genre that upholds freedom, it can also be seen as one that curtails it. For example, though not exclusively, it can be examined as an imperialist discourse through which dominant cultures (white, male, Euro-American, middle-class) seek to integrate themselves often at others' expense. Again, travel writers can be assessed as unreliable documenters of other people and cultures, but they have had a say in the critical reassessment of their own. Thus, travel writing is a valuable medium of estrangement, even if it operates all too frequently through familiar stereotypes and myths. Apart from being reporters of other's worlds, these writers also address to our world, giving us access to cultural regions that, though 'discovered', remain mysterious to us, or make strange those very territories, and the values and attitudes we ascribe to them, that we might imagine being most familiar, the closest to our own experience. Therefore, travel writing can be seen as a useful vehicle of cultural self-perception: as a barometer for changing views on other ('foreign', 'nonwestern') cultures; and as a trigger for the informational circuits that tap us into the wider world. Travel writing, traditionally seen as affording a license for escapism, may yet show its readers the limits of their ambition and remind them of their responsibilities. In negotiating some of these apparent contradictions, travel writers can be seen as cultural commentators, who are capable of trading places; by rhetorical sleight of hand and they may appear as both behind the times and also up to date at the same time. Thus, the title with (/) seems quite apt in the context of travel narratives as these do not look in/into/inside other people, places and culture but also entails an endless set of signifiers in this introspection.

The roots of social and cultural formation in the Northeast are intertwined with a long history of migration of people, ideas as well as traditions into this region. The present modern-day Assam acquired its name from the Ahom rulers who migrated from Southeast Asia, settled and eventually ruled the region for a long period of six hundred years (1228-1826). As their rule progressed, their initial cultural-religious affiliations changed drastically shaping the social and cultural norms and the people inhabiting these regions. The ancient name of Assam i.e. Pragjyotisha finds mentions in the epics the Ramayana and the Mahabharata as well as the Puranas. According to the Kalika-Purana, it was changed to Kamarupa due to its association with the presiding deity Kamakhya and was often referred to as Kamarupa-Kamakhya. However, in epigraphic records, the name Kamarupa was first mentioned in the Allahabad inscription of Samudragupta of 350 C.E. and records it as a frontier kingdom of the erstwhile Gupta Empire. Even Kautilya (200 C.E.) mentions the river Lohitya (Brahmaputra) in his book Arthashastra giving evidence of the knowledge of this region. The Yogini-Tantra and the Kalika-Purana indicate the geographical boundary of the region and mention the Karatoya River in Koch-Bihar as its Western boundary stretching over to include Sylhet as well as Bhutan in the region. Thus, the kingdom of Kamarupa once included almost the whole geographical region of Northeast India, excluding only the kingdoms of Manipur and Tripura which have existed as independent kingdoms for most of their history. It was only in 1949 that these kingdoms were integrated into independent India. It is generally accepted that the Mongoloids, known as the Kiratas in ancient Sanskrit literature, once occupied practically the whole of Northeastern India.

North East India has remained for most of its remembered and even written history as imagined geography and this land of 'durable disorder' (Baruah, 2012, p. xvi) for centuries has been a cross-road for migration. In its long history, it has also caught the attention of foreign travellers and found mention in many travel accounts from pre-historic times. The first amongst these was that of Periplus of the Erythrean Sea ( ${ }^{\text {st }}$ Century) who refers to the tribes of the Northeast collectively as 'Sesatae' while Ptolemy (23-79 C.E.) calls them as 'Besadae'. However, a detailed account of the kingdom of Kamarupa was produced later by the Buddhist travellers Hieun Tsang (602-664 C.E.) in Si-yu-ki (The Records of the Western Records) written around 630 
A.D., and I-tsing (635-713 C.E.) in The Memoirs of Eminent Monks who Visited India and Neighboring Regions in Search of the Law during the Great Tang Dynasty (671-95 A.D.). Interesting accounts of Assam also finds mention in many narratives written by the Turko-Afghans and the Mughals who invaded Assam from time to time but was unsuccessful in capturing or consolidating the whole of Assam. Accounts like Minhaj-i-Siraj's Tabakat-i-Nasiri (1206), Munshi Ghulam Hussain Salim's Riyaz-us-Salatin (A.D. 1787-88), AI-Badaoni's Muntakhabu-t-Tawarikh (1595), Abul Fazal's Akbarnama and Ain-i-Akbari (1592-94), Shihabuddin Talish's Tarikh-i-Assam, Mirza Nathan's Baharistan-I-Ghaybi are worth mentioning in this context.

Though the travel narratives on Assam increased manifold after the British conquest of Assam in 1826, there were many travel narratives even during the pre-colonial period produced by Europeans visiting Assam for various reasons. The foremost amongst them was by Ralph Fitch, an English merchant who visited the Koch Kingdom during the reign of King Naranarayan (1540-87). Fitch arrived at Kochbehar around 1586 and the narrative was included in Richard Hakluyt's The Principal Navigations (1599) and later published as Ralph Fitch, England's Pioneer to India and Burma: His Companions and Contemporaries, With His Remarkable Narrative Told in His Own Words (1899). After Fitch, there are varied pieces of evidence to the Christian missionaries' activities in Assam during the 17th and 18th centuries. This was a time during which the whole of the Indian subcontinent was undergoing sea-change politically and the Northeastern provinces of India too opened up to the entry of Jesuit missionaries and Christianity that quietly made headway into this part of the country. Commenting on this, Milton Sangma states:

The earliest entry of the Christians into the Northeast can be traced much before the advent of British rule. The earliest recorded visit by the Christian missionaries to Northeast India was in 1626 by two Jesuit missionaries, Fr. Stephen Cacella and Fr. John Gabrial, who were probably looking for a passage to Tibet and China. (qtd. in Hussain, 2011, p. 35).

Even the Moghul garrison of Rangamati in Goalpara had a large Christian population with two churches, one dedicated to Our Lady of the Rosary and the other to Our Lady of Guadelupe. It was visited by various missionaries including Frey Sicardo in about 1696, Fr. Barbier S.J. in about 1720 and by Padre Marco della Tomba between 1758 and 1769. Particularly, Bartholomew Plaisted visited Assam in about 1750 and has left a characteristic traveller's tale regarding the people and the province of Assam. In his book entitled Journal from Calcutta in Bengal by Sea to Busserah (Balfora) etc. in the year MDCCL (1767) he gives a detailed account regarding "the Kingdom of Afem or Azem which lies to the South-East of Bengal, and was first discovered by sailing up the River Lakia, which proceeds from the Lake Chemay" (Plaisted, p. 227). He regards it as one of the finest countries in Asia, producing everything for the use of men. He notes that it has "mines of gold, silver, iron and lead along with plenty of silk, borax and gum lack, which they supply to their neighbours." (p. 227). He also adds: "They have no gold coin, but make use of ingots in their way of trade. They are fond of dog's flesh as well as Chinefe, and make use of it in their most splendid entertainments. They have plenty of grapes, of which they make no wine, but brandy or arack." (p. 227) He further adds: "They have no salt but what they get by burning of herbs and leaves of a sort of fig-tree. Of these lefts, they make pot-ashes and use them for blanching their silk." (p. 228). He also provides a vivid description of the physical features of the people of the province.

During the same time frame, it was not only the Westerners but travelogues were also being written in the vernacular. The pioneer amongst travel texts in Assamese is Tripura Buranji (1724) written jointly by Ratna Kandali Sarma and Arjundas Bairagi, the two Assamese envoys of 
King Swargadeo Rudra Singha (1696-1714) who were sent to the court of Ratnamanikya, the King of Tripura in 1714 to seek assistance for the proposed invasion of Bengal. Owing to this event, various correspondences and envoys were being sent to and fro from the Ahom court to the King of Tripura. The two envoys mentioned here also undertook the journey to Tripura on foot accompanied by escorts through Cachar and the foothills of Lushai Hills (present-day Mizoram) to the capital of Ratnamanikya. During the journey, they minutely recorded the natural environment, agricultural products, habits, dress, and manners of people noticed during their journeys. Particularly, they took note of the capital of Tripura, its people, temples dedicated to different deities. Religious beliefs of people, details of Tripura court, and the intrigue for the throne have been vividly narrated in the racy style of the medieval chronicles.

These travelogues are precious testimonials to the political, social, and economic demographics of the period and offer valuable insights about various ethnic communities residing in Northeast India. The chronicle Tripura Buranji derives its importance principally from the circumstances in which it was compiled, the revelations which it contains of the pan-Indian interests of the Assamese monarch Swargadeo Rudra Singha and the panorama of information it provides about the history, topography, resources, and customs of Tripura, and also about the revolution at the capital of Tripura enacted before the eyes of the narrators. Even though the Ahom court and the Tripura court have had a cordial relation in ancient times, there was an interruption in that relationship for quite a period. So, to resume that relationship, Rudra Singha had sent emissaries to the court of Tripura on three different occasions between 1709 and 1715 . The objective of Rudra Singha's emissaries was to establish friendly relations with Tripura in furtherance of his aim to organize a confederacy of Hindu rulers against the invading Moghuls. Rudra Singha planned to reinforce himself before undergoing an invasion of Bengal to avenge the humiliating overtures of its Governor Nawab Murshid Kuli Khan who used to send presents of Khelats, or robes of honour, to Swargadeo Rudra Singha insinuating thereby that the Ahom monarch was subordinate to the Moghuls.

This diplomatic mission was thus undertaken by the Assamese Kataki Ratna Kandali and accompanied by Anandiram Medhi, a Bengali musician, who was intimately known to the Tripura Raja Ratna Manikya (1698-1712). Anandiram Medhi having undertaken to accomplish the objective was sent to Tripura on the pretext of fetching water from the Ganges for the Barbarua Surath Singha and accompanied by Ratna Kandali Sarma and Arjun Das Bairagi. Following the first mission, there were several diplomatic missions between Assam and Tripura in the successive years. It is recorded in the Buranji that the Ahom monarch had received the Tripura envoys Rameswar Nyayalankar and Udaynarayan on July 24, 1711, at his new capital Rangpur amidst the pomp and ceremony on such occasions. In November 1711 the Tripura envoys departed from the Ahom capital in the company of Ratna Kandali and Arjun Das for the second time. The Assamese agents were furnished with paiks to accompany them in their mission to Tripura, 18 for Ratna Kandali and 16 for Arjun Das. The party proceeded from Namdang to Raha and then to Demera wherefrom they went by land to Khaspur, the capital of Cachar. From Khaspur they proceeded to the Tripura capital and passed through the following mountains tracts -Rangrung, Toijalpara, Kumjang, Sairangchuk, Deogang, Chota Marichrai, and Khakrai. From Khakrai the envoys went on horsebacks to the Tripura capital which they reached on $31^{\text {st }}$ March 1712. During the course of their journey, the Assamese envoys recorded the commercial products and the manners and customs of the inhabitants of the territories through which they passed. As an example, the Rangrung hills were inhabited by the Kukis, and their markets were frequented by Kacharis, Manipuris, and Tripurians. 
Regarding Rangrung the envoys write that:

There were no people there. On both sides of the river Barak were mountainous tracts. In these hills lived a tribe of people similar to that of the Nagas of Assam, they were called Kukis. There were about 300 of them. Their armory-arrows, bow, and spears. The chieftain named Halmasha paid tribute to the Tripura king.....Their dress was like the Nagas, and they don't eat beef...Also could be found was Mithun (Cattle of Mountain), Elephant's Tusks, Black Pepper, Betel Leaf and Areca Nut, Rice Grains, Water Melon, etc.(Sarma, p. 22)

Regarding the vegetation and flora and fauna of the following mountainous tracts like Toijalpara, Kumjang, Sairangchuk, Deogang, Chota Marichrai, and Khakrai, the envoys report that: "Everything that was to be found at Rangrung was also available in these regions except that of Betel leaf and Areca Nut..."(p. 23)

On $15^{\text {th }}$ April 1712, the Assamese envoys were formally received by the Tripura Raja. However, before going to the Raja's durbar the envoys instructed two of their camp-followers to follow them to the court in disguise and note the resources of the state and the disposition of the forces. Describing the inhabitants of Tripura, it is noted that "These people drink wine, eat pork, cremate their dead and their funeral rites extend until a month." (p. 23) The information collected by the two "spies" together with the observations of the two Katakis has been embodied in the form of the book Tripura Buranji which has been aptly also subtitled as a chronicle of Tripura in Bengal. In chapter 11, a spatial description of the kingdom of Tripura has been provided and the King's palace is described as:

The king's palace was surrounded on four sides with brick walls, measuring about 6 Haan (about 19.5 foot), similar to the interior walls of Rangpur. Interior to these walls are those made of mud which is similar in length. The total length of these walls would be equal to our walls from Darikial to Borchora...(p. 25)

The next few pages of the book in the conventional fashion of the Buranjis contain the various titular heads of the Tripura court. Various positions such as "Rajbongshi Barthakur, Ujir (a Minister), Nazir(a bailiff), Nemujir, Kotwal, Mushir, etc.”(p. 27) and their functions have been laid out for the readers. However, what is interesting is the fact that the envoys had in mind the target audience of their accounts back home. So, any description is always put out in comparison to the one back home. In the case of the designated positions, for example, the envoys write that the above positions "were similar to that of the Barbaruahs and Phukans of the Ahom kingdom. The only difference was that these were permanent positions and they could never become officers of any other affair."(p. 27) In addition to the three diplomatic missions that had been undertaken by the envoys on both sides, the book also contains various kinds of information on the political turmoil in the courts of Tripura as well as Assam. This included the usurping of the throne of Tripura by Mahendra Manikya on May 10, 1712, and also the demise of the Ahom monarch Rudra Singha during the third expedition of the Assamese envoys to Tripura on August 27, 1714. In chapter 20, the envoys describe the Tripura court and inform how on $18^{\text {th }}$ April 1712 the Tripura king had formally received the Assamese envoys. The book ends with the abandonment of the mission to attack Bengal by the successor, Swargadeo Siva Singha, and the return of the proceeding army and the returning envoys to Gargaon, the old Ahom capital in August 1715.

Comparing both these travel texts, written around the same period, a few points can be discerned. Firstly, though the Assamese or Tripuri were not outsiders from a modern pan-Indian perspective, yet, looking at the geographical divisions of the kingdoms during that period it can 
be said that the Assamese envoys in Tripura and vice-versa were outsiders for the inhabitants of the respective regions. As such, the account of Tripura is also an account of a foreign land by the Assamese envoys. However, it can be seen in the excerpts that the aesthetic conventions and vocabulary used by Bartholemew Plaisted in his description of Assam (also a foreign land) is covertly colonial in nature. He confronted a radically different topography, climate, flora, and fauna, diseases, cultures, and belief systems. Therefore the travelogue, cast as an exploration narrative, takes recourse to a trope of 'discovery' to deal with the new. This, in turn, embodied rhetoric of similarity and difference, taking cues in food habits, physical descriptions, flora, and fauna, etc. of the new land. Secondly, the narrative by Plaisted shows how rhetoric organizes experiences and ideas, making them intelligible and communicating them. Particularly, Jonathan Sell (2006) has argued that English travel writers in India from the sixteenth century onwards, has adhered to narrative models prescribed to them by their predecessors. Such lists and inquiries, which were quite prevalent at that period, took into account everything, from the manners of the people to the soil's fertility. These histories, like maps, systematically characterized and categorized the otherwise unknown into a more orderly and comprehensible form. Plaisted too seemed to have followed the process of cataloguing of India and follows the detailed pattern that has also been exhibited by Sir Edward Terry (1590-1660), Sir Walter Raleigh (1552-1618), and other English travellers of the seventeenth century.

The descriptive account of a foreign land has also been provided in the Tripura Buranji, however, there is a slight difference in both the narratives. The patterned cataloguing which is visible in Plaisted's account is missing in the case of the vernacular one. Thirdly, Peter Hulme had formulated colonial discourse to be, "an ensemble of linguistically based practices unified by their common deployment in the management of colonial relationships." (1992, p.2) It showcases that colonial discourse is not simply a set of linguistic devices. On the contrary, in the words of the noted critic Stephen Greenblatt, "they do much of the crucially important work of colonialism." (1993, p. xvi). Thus, different aesthetic approaches in colonial discourse construct particular images of India as a preliminary to English interpretation, governance, and alteration. The informing assumption, therefore, is that aesthetic modes and their narrative structures act as contexts for and narrative methods of colonial 'action', often suggesting a rhetorical-textual control over India. The discourse of Plaisted is a case example of how the narrative ordering of India in the seventeenth-century travelogue was greatly facilitated and informed by projecting India as the marvelous. The descriptive vocabulary of these early travel narratives reveals particularly extensive use of the two tropes of 'variety' and 'otherness' which are embodied in the 'marvelous'. Together, variety and otherness construct a strange and wondrous India, simultaneously frightening and fascinating at the same time. This invokes feelings of awe and revulsion and demands investigation and interpretation from an 'informed' traveller. Troping India as a wondrous, if difficult 'space', enables English travellers to carve out a definitive role for themselves as the 'marvelous' demands investigation, inquiry, and interpretation. Thus, the marvelous was an explanatory and exploratory aesthetic that enabled the traveller to wonder at, organize, define, and ultimately explain (away) India's newness.

\section{Bibliography}


Baruah, S. (2012). Durable Disorder: Understanding the Politics of North East India. Oxford University Press, 2012.

Butor, M. (1974). “Travel and Writing”. Mosaic. Fall 1974, vol. 8, no. 1, 1-16.

Fussell, P. (1982). Abroad: British Literary Traveling Between the Wars. Oxford University Press.

Greenblatt, S. (ed.) (1993). New World Encounters. Berkeley, CA: University of California Press.

Hulme, P. (1992). Colonial Encounters: Europe and the native Caribbean, 1492-1797. London: Routledge.

Hussain, M. (2011). The Assamese Christians. Guwahati: Purbanchal Prakash, 2011.

Plasited, B. (1758/1767). A journal from Calcutta in Bengal, by sea, to Busserah : from thence across the great desart to Aleppo: and from thence to Marseilles, and thro' France to England In the year MDCCL. London: Printed for T Kinnersly, in St. Paul's Church-Yard.

Pratt, M L. (1992). Imperial Eyes: Travel Writing and Transculturation. London: Routledge.

Sarma, Ratna Kandali. (1724). Tripura Buranji. Rpt. (1938). Guwahati: Department of Historical and Antiquarian Studies.

Sell, J. P.A. (2006). Rhetoric and Wonder in English Travel Writing, 1560-1613. UK: Ashgate Publishing Ltd.

Swift, J. (1726). Gulliver's Travels. Rpt. (2008) Oxford: Oxford University Press. 